\title{
Video Tutorials: An Appropriate Way of Teaching Quality Management Tools Applied with Software
}

DOI: 10.12776/QIP.V20I2.754

\author{
Jane Worlitz, Anne Stabler, Stefan Peplowsky, Ralf Woll
}

Received 04 June 2016, Revised 20 July 2016, Accepted 04 September 2016

\begin{abstract}
Purpose: The aim of this research is to verify the applicability of video tutorials for the improvement of software skills.

Methodology/Approach: Video tutorial prototypes were created according to design criteria found in literature and tested as teaching material of selforganized/self-regulated learning. 65 students were parted in two groups and asked to work on an assignment concerning the use of quality tools in Microsoft Excel. One group used video tutorials and the other group was guided by a teacher. Before and after the assignment the students were asked to fill out a survey evaluating their software skills as well as the aid used during the test.
\end{abstract}

Findings: The results of the survey do not show a significant difference between the evaluation of video tutorials and guidance of the teacher. Also the performance of both groups concerning the assignment was comparable. From these findings it can be concluded that video tutorials and classroom teaching are equal ways of teaching in the investigated field.

Research Limitation/implication: The suitability of video tutorials for the application of quality-tools with the use of appropriate software has been confirmed. The results do not show conclusions about the extent to which video tutorials can be suitable for the mediation of complex issues. Follow-up studies are required for this purpose.

Originality/Value of paper: The study demonstrates that video tutorials, as a form of self-organized/self-regulated learning, are suitable to improve skills in applying quality tools by using software.

Category: Research paper

Keywords: video tutorial; education; knowledge transfer; quality tools; software 


\section{INTRODUCTION}

In the past years video tutorials became a wide spread method of transmitting instructions for the use of software (van der Meij and van der Meij, 2014). There are three main factors for the recent development of using video tutorials for software learning. On the one hand there is a rising request for new or updated software programs that users demand instructions for. On the other hand there is a fast improvement of easy-to-use software programs such as Camtasia, Sceencast-O-Matic or QuickTime which are brought to the market from the supply side. Additionally, a quick and easy way of uploading video tutorials on internet platforms such as YouTube has facilitated the distribution of videos and allows reaching a wide audience (van der Meij and van der Meij, 2013).

The academic teaching has also been affected from these changes, due to an increased interest of using new media and technologies as well as the internet and internet-based learning systems. The advantages of online learning have become widely approved (Saadé, Bahli, 2005). The popularity of computer-based learning and video tutorials in particular has likewise influenced the way of transferring knowledge in higher education institutions such as universities. In contrast to a tutoring class that has to be scheduled and requires a time commitment of several people at the same time, video tutorials can fix deficits among students through self-organized/self-regulated learning as a study from 2012 has shown for a university chemistry class. This study found out that video tutorials compared to live tutors were also a convenient tool to improve students' performance in class (He, Swenson and Lents, 2012).

\subsection{Analysis of the problem situation - recognition of competence gaps}

Computer skills are in today's professional life often essential. The computer is one of the most used means of employed persons. A study by the Statistical Office of the European Union revealed that in Europe in 2014, 52\% of employees regularly used a computer. In Germany, it was $61 \%$ in 2013. The use of computers increases the productivity and efficiency of businesses and industries of all sizes and thus makes them more competitive (Eurostat, 2015a). In 2014, the Statistical Office of the European Union published a statistic about the computer skills of the European population. It was found that $45 \%$ of the respondents have low or no computer skills. Only $44 \%$ of the 16-74-year-olds have knowledge of the application of simple formulas in spreadsheets. Among the 16-24-year-olds there are $65 \%$ possessing this kind of knowledge. In Germany, $48 \%$ of the 16-74-year-olds have knowledge of the application of simple formulas in spreadsheets and 63\% of the 16-24-year-olds (Eurostat, 2015b). Skills on how to use statistical and spreadsheet software is required in many areas, including quality management. Nowadays, it is a rare case that companies write their quality control charts by hand or use a calculator to determine the correlation coefficients. For this reason, it seems useful to promote 
the acquisition of the required competencies in this area at an early stage. It is necessary to regard the heterogeneity of the learner's prior knowledge in order to perform a successful knowledge transfer. At the same time the method should be as resources efficient as possible. A study examining the impact of video tutorials and instructor feedback on skill acquisition in the medical field suggested that using video tutorials can minimise the need for instructor involvement and therefore reduce costs (Stefanidis, et al., 2007).

\subsection{Identification of a possible approach - self-organized or self- regulated learning as a learning concept}

Objectives of self-organized/self-regulated learning include the increase of selfresponsibility for ones own learning (Witten, Penon and Dietz, 2006). The concept of self-organization or self-regulation of learning processes can be found in all areas of education. It starts with school education and is also used in university education, vocational training and in adult education (Baumeister, 2004). Self-organized/self-regulated learning emerges from the 1970 s movement of changing from teacher-centered approaches towards student-centered approaches (Schunk, 2004). The self-organized/self-regulated learning means a methodical activation of cognitive, motivational and behavioral processes for the achievement of educational targets (Zimmermann, 2008). Self-organized/selfregulated learning creates a number of positive effects. It leads to faster learning and a long-lasting memory due to the activation processes. The motivation of the learner will be extended through the use of practical actions. Furthermore, the flexibility of the learning content and the self-regulated time management of the learning activities are advantages of self-organized/self-regulated learning (Preißer, 2006). The application of methods of self-organized/self-regulated learning can cause a positive effect on students' academic performance. It has been reported that self-organized/self-regulated learners are more effective, efficient and productive compared to other students (Wolters, 2010). Since there is an increasing demand for a lifelong learning, the ability of technology-based self-organized/self-regulated learning will become more and more important in addition to traditionally organized learning offerings (Kalz, Koper and HornungPrähauser, 2009). E-learning, which means electronically supported learning, is such a technology-based form of learning which became increasingly popular due to the fast development of computer technology. Another reason for its popularity is the access to an extensive amount of information (Low and Putaj, 2012). The most important characteristic of e-learning is the ability of including various kinds of media, like graphics, audios and videos in order to generate instructional material (Sun and Cheng, 2007). It can be used both online and offline. For this form of learning computers and the internet are used, either to impart knowledge, or to support learning processes (Ehlers, 2011). The aim of elearning is to design educational offers in an adequate and innovative way. Moreover, e-learning should help increase the chance of a fair educational access (Revermann, 2009). 
The smallest meaningful learning unit of e-learning is a learning object. A video tutorial can be regarded as a learning object (Revermann, 2009). Learning objects represent a new way of managing learning content. They can be used separately as a single learning unit or grouped to create a collection of content, for example in order to structure a whole course. They can be applied in various contexts and they are reusable (Chiappe, Segovia and Rincon, 2007). In contrast to a common believe that watching videos could be a passive action, studies report that watching learning videos can cause high cognitive action that is needed for active learning (Mayer, 2001). There are a couple of reasons why videos can trigger active learning. Videos respond to multiple intelligences as they use different styles of delivering content and they have an emotional affect on the viewer (Gardner, 2006). Information is transmitted both through the aural and visual channel which creates a richness of input that can lead to remembering the information better (Mayer, 2001). By stimulating two senses at once video tutorials become suitable for different types of learners (Fortino and Zhao, 2012). An advantage of video tutorials is the adaptability to the individual learning pace. Video tutorials can be played any number of times; they can be stopped, repeated and skipped over sequences (Revermann, 2009). However, a disadvantage of video tutorials is the relatively time-consuming creating process (Niegemann, 2004). Video tutorials can, for example be offered by educational institutions as an additional learning material for a seminar or an online course. For some university courses, like the teaching of laboratory skills in biology, a blended approach of combining face-to-face-teaching with video tutorials has been suggested as the most successful way of teaching practical skills (Truebano and Munn, 2015). The use of video tutorials for different areas of learning at universities and schools has been analyzed in a number of studies. In the following Table 1, a review of literature regarding the effect of video tutorials on learning outcomes is presented. Further studies dealing with this topic can be found from authors such as Morgan, et al. (2002); Balslev, et al. (2005); Boster, et al. (2006); Coffee and Hillier (2008); Jones, et al. (2010) and van der Meij and van der Meij (2014). All studies confirm that the learning performances supported by the use of video tutorials are similar to those supported by a teacher or other teaching materials. In some cases, the groups that used video tutorials even performed better. The suitability of video tutorials for teaching software skills in quality management has not been examined in the collected studies. 
Table 1 - Literature review

\begin{tabular}{|c|c|c|c|}
\hline author, year, title & data base & $\begin{array}{l}\text { method and research } \\
\text { question }\end{array}$ & results \\
\hline $\begin{array}{l}\text { Siegel, P.H./ } \\
\text { Omer, K./ } \\
\text { Agrawal, S.P., } \\
\text { 1997, } \\
\text { Video simulation } \\
\text { of an audit: an } \\
\text { experiment in } \\
\text { experiential } \\
\text { learning theory. } \\
\text { Accounting } \\
\text { Education } 6\end{array}$ & $\begin{array}{l}\text { The participants of } \\
\text { this study were } \\
\text { students of the } \\
\text { introductory course } \\
\text { of accountancy. } \\
\text { Two groups were } \\
\text { compared, the } \\
\text { introductory course } \\
\text { of the winter } \\
\text { semester with the } \\
\text { introductory course } \\
\text { of the summer } \\
\text { semester. } \\
\text { I: (WS) } n=40 \\
\text { II: (SS) } n=60\end{array}$ & $\begin{array}{l}\text { The aim of the study } \\
\text { was to examine the } \\
\text { effects of learning } \\
\text { videos for the students } \\
\text { of the accountancy } \\
\text { course. The first group } \\
\text { received instructions } \\
\text { by a video tutorial in } \\
\text { addition to the regular } \\
\text { lecture, while the } \\
\text { second group only } \\
\text { attended the lecture. }\end{array}$ & $\begin{array}{l}\text { The study showed that the } \\
\text { students of the first group } \\
\text { were significantly better in } \\
\text { the course sections than the } \\
\text { second group, who had no } \\
\text { learning video. The author } \\
\text { indicates that all students } \\
\text { who participated in the } \\
\text { experiment had the same } \\
\text { starting conditions. }\end{array}$ \\
\hline $\begin{array}{l}\text { Stefanidis, D./ } \\
\text { Korndorffer, J. R./ } \\
\text { Heiniford, B. T./ } \\
\text { Scott, D. J, 2007, } \\
\text { Limited feedback } \\
\text { and video tutorials } \\
\text { optimise learning } \\
\text { and resource } \\
\text { utilisation during } \\
\text { laparoscopic } \\
\text { simulator training }\end{array}$ & $\begin{array}{l}\text { The Participants of } \\
\text { this study were } 34 \\
\text { medical students, } \\
\text { divided into three } \\
\text { groups: } \\
\text { I: } 1 \text { x video tutorial } \\
+ \text { intense feedback } \\
\mathrm{n}=9 \\
\text { II: } 1 \text { x video } \\
\text { tutorial + limited } \\
\text { feedback } \mathrm{n}=13 \\
\text { III: several times } \\
\text { video tutorial }+ \\
\text { limited feedback } \mathrm{n} \\
=12\end{array}$ & $\begin{array}{l}\text { The aim of the study } \\
\text { was to determine the } \\
\text { influence of instructor } \\
\text { feedback and video } \\
\text { tutorials on the } \\
\text { performance during } \\
\text { laparoscopic simulator } \\
\text { training. }\end{array}$ & $\begin{array}{l}\text { All groups achieved the } \\
\text { proficiency level for two } \\
\text { attempts in a row. The } \\
\text { group watching the video } \\
\text { several times and having } \\
\text { limited feedback (group III) } \\
\text { needed the shortest time } \\
\text { and number of repetitions } \\
\text { to reach proficiency with } \\
\text { statistically significant } \\
\text { differences compared to } \\
\text { group I. Using video } \\
\text { tutorials in combination } \\
\text { with limited instructor } \\
\text { feedback was found to be } \\
\text { the best method. }\end{array}$ \\
\hline $\begin{array}{l}\text { DeVaney, T.A., } \\
2009, \\
\text { Impact of Video } \\
\text { Tutorials in an } \\
\text { Online } \\
\text { Educational } \\
\text { Statistics Course }\end{array}$ & $\begin{array}{l}\text { The participants of } \\
\text { this study were } 78 \\
\text { students of an } \\
\text { online statistics } \\
\text { course. }\end{array}$ & $\begin{array}{l}\text { The aim of the study } \\
\text { was to evaluate the } \\
\text { attitude of students } \\
\text { towards video tutorials } \\
\text { and to examine } \\
\text { differences in } \\
\text { performance between } \\
\text { lessons in which video } \\
\text { tutorials were used } \\
\text { and lessons where no } \\
\text { video tutorials were } \\
\text { used. For this purpose } \\
\text { the course participants } \\
\text { filled an on-line } \\
\text { questionnaire with } \\
\text { nine items using a 5- } \\
\text { point Likert scale. }\end{array}$ & $\begin{array}{l}\text { The study found that video } \\
\text { tutorials were an effective } \\
\text { component of the course. } \\
75 \% \text { said the videos were } \\
\text { enjoyable and interesting. } \\
85 \% \text { said the videos met } \\
\text { their needs. } 90 \% \text { believed } \\
\text { that the content was easier } \\
\text { to understand while } \\
\text { watching a video than } \\
\text { reading it in a book. There } \\
\text { was no significant } \\
\text { difference in the } \\
\text { performance of students in } \\
\text { the tutorial and non-tutorial } \\
\text { sections of the course. }\end{array}$ \\
\hline
\end{tabular}




\begin{tabular}{|c|c|c|c|}
\hline author, year, title & data base & $\begin{array}{l}\text { method and research } \\
\text { question }\end{array}$ & results \\
\hline $\begin{array}{l}\text { He, Y./ Swenson, } \\
\text { S./ Lents, N., } \\
2012, \\
\text { Online video } \\
\text { tutorials increase } \\
\text { learning of } \\
\text { difficult concepts } \\
\text { in an } \\
\text { undergraduate } \\
\text { analytical } \\
\text { chemistry course }\end{array}$ & $\begin{array}{l}\text { The participants of } \\
\text { this study were } 27 \\
\text { students enrolled in } \\
\text { an undergraduate } \\
\text { analytical } \\
\text { chemistry course. }\end{array}$ & $\begin{array}{l}\text { The study aims to } \\
\text { evaluate the inclusion } \\
\text { of video tutorials, as } \\
\text { an additional learning } \\
\text { aid, in an } \\
\text { undergraduate } \\
\text { analytical chemistry } \\
\text { course. The } \\
\text { effectiveness of the } \\
\text { video tutorials was } \\
\text { tested by looking at } \\
\text { the pre- and post- } \\
\text { video-tutoring exam } \\
\text { performance, a } \\
\text { comparison to data } \\
\text { from previous classes } \\
\text { and an oral and } \\
\text { written feedback of } \\
\text { the students. }\end{array}$ & $\begin{array}{l}\text { The study shows that video } \\
\text { tutorials are a valuable, } \\
\text { flexible and cost-effective } \\
\text { tool to help students with } \\
\text { their chemistry problems. }\end{array}$ \\
\hline $\begin{array}{l}\text { Truebano, M./ } \\
\text { Munn, C., 2015, } \\
\text { An evaluation of } \\
\text { the use of video } \\
\text { tutorials as } \\
\text { supporting tools } \\
\text { for teaching } \\
\text { laboratory skills in } \\
\text { biology }\end{array}$ & $\begin{array}{l}\text { The participants of } \\
\text { this study were } \\
\text { undergraduate } \\
\text { students with } \\
\text { minimal experience } \\
\text { in a laboratory } \\
\text { environment. They } \\
\text { were divided in } 3 \\
\text { groups: } \\
\text { I: Face-to-face } \\
\text { training only } n=5 \text {, } \\
\text { II: face-to-face } \\
\text { training + video n } \\
=4 \text {, } \\
\text { III: video only } n= \\
5 \text {. }\end{array}$ & $\begin{array}{l}\text { The study aims to } \\
\text { assess the use of video } \\
\text { tutorials in a } \\
\text { laboratory-based } \\
\text { molecular biology } \\
\text { class and to find out } \\
\text { how video tutorials } \\
\text { affect students } \\
\text { confidence when first } \\
\text { facing the laboratory } \\
\text { procedure alone. }\end{array}$ & $\begin{array}{l}\text { This study shows that a } \\
\text { blended approach, using } \\
\text { face-to-face training plus } \\
\text { video tutorials, led to the } \\
\text { best performance among } \\
\text { the tested students when } \\
\text { facing the procedure alone. } \\
\text { Using the video increased } \\
\text { students' confidence of } \\
\text { carrying out the procedure } \\
\text { alone. }\end{array}$ \\
\hline
\end{tabular}

\section{METHODOLOGY}

\subsection{Developing a solution - creating video tutorial prototypes}

In order to carry out a study that examines the effectiveness of video tutorials for the imparting of knowledge for the application of quality management tools with statistical and spreadsheet software, video tutorial prototypes were developed. Before creating the prototypes, general requirements were determined for the design of video tutorials. 
Becher identified two design criteria for video tutorials through an analysis of video tutorials from the online platform YouTube. On the one hand video tutorials should be designed to the learners taste, concerning the content and language, the speech speed, the pronunciation, the introduced examples and visualizations as well as the authenticity of the video. Secondly, the video tutorial should have a clear structure, thus learning content can be easily captured. Outline and objectives, as well as repeating elements and processes contribute to a familiarity with the video tutorial (Becher, 2012).

Van der Meij and Van der Meij developed special guidelines for the design of video tutorials that give instructions for software. Videos for software training should be created in a way that improves the learner's procedural knowledge. The videos should therefore be a recorded demonstration showing how to solve a certain software task, in combination with spoken instructions directing the learner's attention to the important software elements such as menus and icons. Eight guidelines should be regarded during the creation of such a video: 1. Provide easy access, 2. Use animation with narration, 3. Enable functional interactivity, 4. Preview the task, 5. Provide procedural rather than conceptual information, 6. Make tasks clear and simple, 7. Keep videos short and 8. Strengthen demonstration with practice (van der Meij and van der Meij, 2013). The Table 2 contains a summary catalogue of didactic design options for video tutorials.

Table 2 - Literature Didactic design possibilities of video tutorials (Wieser, 2010)

\begin{tabular}{|c|c|c|c|}
\hline 1. Create attention & 2. Clarify relevance & $\begin{array}{l}\text { 3. Pursue volitional } \\
\text { strategies }\end{array}$ & $\begin{array}{l}\text { 4. Promote } \\
\text { autonomous action }\end{array}$ \\
\hline $\begin{array}{ll}\text { method: } \\
- & \text { animations } \\
- & \text { graphics } \\
- & \text { impressive } \\
& \text { images/ facts } \\
- & \text { provocative } \\
& \text { statements } \\
- & \text { questions }\end{array}$ & $\begin{array}{ll}\text { method: } \\
- & \text { formulation of } \\
& \text { objectives } \\
- & \text { development of } \\
& \text { correlated } \\
& \text { qualification } \\
- & \text { illustration of } \\
& \text { results sequence } \\
& \text { relationships }\end{array}$ & $\begin{array}{ll}\text { method: } \\
- & \text { alternative } \\
& \text { solutions } \\
- & \text { surprise effects } \\
- & \text { information } \\
& \text { concretization } \\
- & \text { further reading }\end{array}$ & \begin{tabular}{ll}
\multicolumn{2}{l}{ method: } \\
- & summaries \\
- & flashbacks \\
$-\quad$ & rehearsal \\
& questions
\end{tabular} \\
\hline \begin{tabular}{ll}
\multicolumn{2}{l}{ intention: } \\
- & to arouse interest \\
- & picturing of \\
& learning content
\end{tabular} & $\begin{array}{ll}\text { intention: } \\
\text { - } & \text { emphasizing the } \\
& \text { practical benefits } \\
- & \text { promote success } \\
& \text { confidence }\end{array}$ & $\begin{array}{ll}\text { intention: } \\
- & \text { individualization } \\
- & \text { increase } \\
& \text { concentration } \\
- & \text { promote joy of } \\
& \text { learning }\end{array}$ & $\begin{array}{ll}\text { Intention: } \\
- & \text { create reference } \\
& \text { to reality } \\
- & \text { strengthen } \\
& \text { capabilities } \\
- & \text { test your } \\
& \text { knowledge }\end{array}$ \\
\hline
\end{tabular}

Three video tutorial prototypes were developed in accordance with the design requirements. The video shows how to create a histogram, a Pareto analysis and a control chart with Microsoft Excel. The three different quality tools were used due to their proven different complexity (Worlitz and Woll, 2015). Microsoft 
Excel was chosen because of the expected heterogeneity of knowledge of this software (Eurostat, $2015 \mathrm{~b}$ ). The video tutorials were recorded with the software Camtasia Studio 8 by TechSmith and have a duration time of 8,10 and 13 minutes. For all videos the computer screen was recorded during the application of quality tools with Microsoft Excel and afterwards, comments were added using a headset. Since the prototypes were tested in groups consisting of German students, the voice-over is in German. The application of quality tools was illustrated by a sample tasks. The structural setup of all three video tutorials followed the same pattern. First, an outline showing the processing steps of each task is presented. Then the definition and the finished chart are displayed, so that the learners already get an idea of the final result of the task at the beginning.

For each video it is ensured that the faded in elements are always designed and arranged in the same manner, in order to create regularity in the structure of the videos and to produce a recognising value. The chair logo is displayed in the upper right corner of the video tutorials. This will also increase the brand recognition and authenticity of the video. Next, the sample task is performed and narrated step by step. For each step the respective structure point is faded in for orientation. Also, the logo is retained in each newly inserted Excel spreadsheet. To understand important steps better, animated arrows and framings are used in the videos. The visual highlight is supposed to increase the attention of video users.

The voice-over descriptions are spoken with a suitable pace of speech and a distinct pronunciation. Since the video tutorials are supposed to be used to support University lessons, the language level of the comments is target grouporiented. The video tutorials are not only limited to description of necessary procedures in Microsoft Excel. Scientific facts concerning QM tools and a subsequent interpretation of the results are part of the videos. Most of the captured design requirements have been used in the preparation of the prototypes to ensure the suitability of the videos.The six work packages of structuring, selecting a sample task, preparing the workbook, image recording, sound recording and postproduction took at least half an hour each per video tutorial. The creation of a prototype took therefore three to four hours.

\subsection{Evaluation of the solution - evaluation of experiments with experimental groups}

\section{Objectives and theoretical construction of the survey}

For the intended purpose of examining the impact and the suitability of video tutorials, a survey of students was carried out. The survey is intended to clarify whether the use by video tutorials is perceived as comparably helpful by the test persons $(\mathrm{H} \mathrm{Oa})$ and if it delivers comparable results $(\mathrm{H} \mathrm{Ob})$ to the personal supervision by a teacher. Furthermore it should be investigated whether the processing time differs between the use of video tutorials and personal 
supervision $(\mathrm{H} \mathrm{Oc})$, and whether or not video tutorials are suitable for students with heterogeneous prior knowledge $(\mathrm{H} \mathrm{Od})$. For this purpose four zero hypotheses are established from the following alternative hypotheses.

$\mathrm{H}$ 1a The type of aid used (video tutorial or teacher) has an influence on the assessment of the aid's suitability to solve the given task.

$\mathrm{H} 1 \mathrm{~b}$ The type of aid used (video tutorial or teacher) has an influence on the students' results of the given task.

H 1c The type of aid used (video tutorial or teacher) has an impact on the time taken by the students for the given task.

$\mathrm{H}$ 1d The previous knowledge of the students in Microsoft Excel has an impact on whether or not they want video tutorials for this topic.

In addition to the four hypotheses, it will be examined, which patterns of video tutorials-use already exist among students and which requirements they have for video tutorials.

\section{Database of the survey and survey strategy}

Students of the course "Fundamentals of quality teaching" at the Brandenburg Technical University of Cottbus-Senftenberg were the participants of the survey. An optional supplementary seminar was offered to students of the course to practice the application of quality tools with Microsoft Excel. The seminar was attended by 65 students, aged between 19 and 28 years. $62 \%$ of the participants study Business Administration, 32\% Industrial Engineering and $7 \%$ in other technical disciplines.

The study participants were randomly divided into two groups and carried out the seminar in two different rooms (group $1 \mathrm{n}=31$ and group $2 \mathrm{n}=34$ ). Each of the two groups was divided again in three sub-groups. One of the three quality tools histogram, Pareto analysis or quality control chart was assigned to each supgroup. Both groups worked on the same sample tasks. The first group got assistance by a teacher to handle the tasks. The second group used the video tutorial prototypes. The same instructor was involved in the development of the video tutorial prototypes in order to exclude the possibility that personal characteristics of the teacher or video producer influence the test procedure. The students of both groups were asked to fill out a questionnaire before and after the seminar. The survey was carried out anonymously. By using identification numbers it was possible to match the questionnaires. It took about ten minutes to complete the survey. The two questionnaires were designed as follows.

The first questionnaire, which was completed before the seminar, contained a small introductory text followed by a collection of personal data of the students, such as age, degree, gender, semester and personal Microsoft Excel skills. It was further asked whether or not the person has already visited Microsoft Excel training courses, how often the person uses Excel, and what they expect from the seminar. The introductory text was a brief clarification of the survey project, 
without giving too much information. The data about knowledge and use of Microsoft Excel were collected in order to determine if the students have already had experience with this program and if there is a connection between Microsoft Excel-knowledge and the desire for video tutorials.

After the seminar, a second questionnaire was filled out by the students. In this part of the survey, students were supposed to evaluate how well they were able to manage the task using their assigned aid. This was followed by questions concerning video tutorials. The students were asked about their usage patterns, their wishes and needs in terms of video tutorials. The design requirements of video tutorials were determined based on previously acquired general design criteria. The data of the second questionnaire were evaluated to determine, if students consider video tutorials as an appropriate teaching method, if they want video tutorials in the university as teaching means and what demands they impose on a video tutorial. As a further data source the results of the tasks completed by the students in the seminar were included to determine whether the two groups showed differences in their performances.

\section{Analysis and results of the survey}

The software SPSS IBM and Microsoft Excel were used for the data analysis of this study. All four hypotheses were tested by a single factor variance analysis of a significance level of 0.05 . The data were tested for the suitability of an application of variance analysis. Using the Levene test and the KolomogorovSmirnov test, the data were tested for variance homogeneity and normal distribution. Since the variance analysis is resistant to violations of the mentioned application requirements (Toutenburg and Knöfel, 2007), it is used here as the method of data analysis despite small premise deviations of some variables.

An influence of the used sample tasks and consequently the degree of complexity of the quality management tools on the results has not been found. For this reason, the following analysis is not specified by the type of sample task. In the first step it was examined whether the type of method used (video tutorial or teacher) has an impact on the dependent variable "assessment of each method". The variance analysis proved that the evaluation of the video-tutorial and teacher did not differ significantly in the two examined groups. The alternative hypothesis $\mathrm{H} 1 \mathrm{a}$ has not been confirmed (see Table 3). 
Table 3 - ANOVA Test on HOa

\section{One way factorial ANOVA}

How helpful was the assistance to the task?

\begin{tabular}{|c|c|c|c|c|c|}
\hline & $\begin{array}{c}\text { Sum of } \\
\text { square }\end{array}$ & df & $\begin{array}{c}\text { Mean } \\
\text { square }\end{array}$ & F & Significance \\
\hline $\begin{array}{c}\text { Between the } \\
\text { groups }\end{array}$ & .333 & 1 & .333 & .098 & $\underline{.756}$ \\
\hline $\begin{array}{c}\text { Within the } \\
\text { groups }\end{array}$ & 214.652 & 63 & 3.407 & & \\
\hline Total & 214.985 & 64 & & & \\
\hline
\end{tabular}

In the second step, it was examined if the type of method used (video tutorial or teacher) has an effect on the dependent variable "task performance". The variance analysis showed that the results of the sample task of the two groups do not differ significantly. The alternative hypothesis $\mathrm{H} 1 \mathrm{~b}$ was not confirmed (see Table 4).

Table 4 - ANOVA Test on $\mathrm{HOb}$

\section{One way factorial ANOVA}

How well was the task accomplished?

\begin{tabular}{|c|c|c|c|c|c|}
\hline & $\begin{array}{c}\text { Sum of } \\
\text { square }\end{array}$ & df & $\begin{array}{c}\text { Mean } \\
\text { square }\end{array}$ & F & Significance \\
\hline $\begin{array}{c}\text { Between the } \\
\text { groups }\end{array}$ & .463 & 1 & .463 & .271 & $\underline{.605}$ \\
\hline $\begin{array}{c}\text { Within the } \\
\text { groups }\end{array}$ & 88.741 & 52 & 1.707 & & \\
\hline Total & 89.204 & 53 & & & \\
\hline
\end{tabular}

In the third step, it was examined whether the type of method used (video tutorial or teacher) has an effect on the dependent variable "processing time". The variance analysis showed that the processing time of the accomplishment of the sample task between the two groups does not differ significantly. The alternative hypothesis $\mathrm{H}$ 1c has not been confirmed (see Table 5).

Table 5 - ANOVA Test on HOc

\section{One way factorial ANOVA}

Processing time for the task in minutes

\begin{tabular}{|c|c|c|c|c|c|}
\hline & $\begin{array}{c}\text { Sum of } \\
\text { square }\end{array}$ & df & $\begin{array}{c}\text { Mean } \\
\text { square }\end{array}$ & F & Significance \\
\hline $\begin{array}{c}\text { Between the } \\
\text { groups }\end{array}$ & 270.909 & 1 & 270.909 & 2.794 & $\underline{.107}$ \\
\hline $\begin{array}{c}\text { Within the } \\
\text { groups }\end{array}$ & 2521.198 & 26 & 96.969 & & \\
\hline Total & 2792.107 & 27 & & & \\
\hline
\end{tabular}


The processing time was in average about 30 minutes. The maximum was 50 minutes and the minimum was 9 min. The time was only started to be measured after explaining the task. In the fourth step, it was tested if the level of knowledge of the subjects has an influence on the desire for video tutorials. The variance analysis showed that there was no significant difference in the desire for video tutorials between the groups. The hypothesis $\mathrm{H} 1 \mathrm{~d}$ has not been confirmed (see Table 6).

Table 6 - ANOVA Test on HOd

One way factorial ANOVA

Would you want VT for Excel knowledge improvement?

\begin{tabular}{|c|c|c|c|c|c|}
\hline & $\begin{array}{c}\text { Sum of } \\
\text { square }\end{array}$ & df & $\begin{array}{c}\text { Mean } \\
\text { square }\end{array}$ & F & Significance \\
\hline $\begin{array}{c}\text { Between the } \\
\text { groups }\end{array}$ & .630 & 5 & .126 & .984 & $\underline{.436}$ \\
\hline $\begin{array}{c}\text { Within the } \\
\text { groups }\end{array}$ & 7.042 & 55 & .128 & & \\
\hline Total & 7.672 & 60 & & & \\
\hline
\end{tabular}

Out of the 65 students surveyed, 50 students expressed the desire for video tutorials for the application of quality management tools using Microsoft Excel.

In average, the students evaluated their Microsoft Excel skills with a value of 3.2 on a Likert scale of 1-7 (very low - very good knowledge). Most students rated their Microsoft Excel skills to be rather low. 11\% of the test persons had visited a Microsoft Excel course. When asked how many students use Microsoft Excel, $56 \%$ said that they use Microsoft Excel on a monthly basis.

The survey captured the importance of certain requirements to design criteria for video tutorials. The students were asked to evaluate the personal importance of characteristics of a video tutorial on a Likert scale of 1-7 (not important - very important). The analysis shows that the students find that the technical accuracy of the video tutorials is the most important and the speaker's voice is the least relevant characteristic. However, none of the criteria have been considered as absolutely insignificant. All design criteria were rated with an average of at least 4.8. When asked if they believe that video tutorials are an appropriate aid to complete the given tasks, $92 \%$ of the participants answered with yes.

\section{CONCLUSION}

The survey has shown that students evaluate their Microsoft Excel skills in average as rather low. Very few students have already attended Microsoft Excel trainings and most students do not yet use Microsoft Excel daily or weekly. From this it can be concluded that most students do not work often with Microsoft Excel, and therefore have no distinct knowledge. The survey shows that almost 
all students expressed the desire for specific video tutorials; which means that students are interested in compensating the deficits in this area. Even students, who perceived their Microsoft Excel skills as medium or high, showed interest in video tutorials of this kind in order to improve their skills. The demand for video tutorials for the application of quality management tools with Microsoft Excel is consequently given.

Both test groups estimated that their assigned aids to complete the tasks in the seminar were equivalent. From the perspective of students, there is no significant difference whether or not the knowledge to be learned is transmitted by a teacher or by a video tutorial. The review of the performances in the seminar and the processing time confirmed the equivalence of the performance of both groups. Furthermore, the complexity of the quality management tool did not influence the results. From this can be concluded that video tutorials are as suitable for teaching Microsoft Excel knowledge for the application of quality management tools as the mediation by the teaching staff. The use of video tutorials as an additional learning material can therefore be approved. At this point it should be noted that only the suitability of video tutorials for the application of qualitytools with the use of appropriate software has been confirmed. The results do not show conclusions about the extent to which video tutorials can be suitable for the mediation of complex issues. Follow-up studies are required for this purpose.

The evaluation of the design criteria of video tutorials confirms the relevance of compliance with the general design criteria for the creation of prototypes. Based on the results, priorities for the creation of further video tutorials can be regarded. The initial investment in the video tutorial production is approximately three to four working hours for trained developers. Further, suitable software and hardware for video and audio recordings is required. A video tutorial can be used for a limited time due to software updates. In Microsoft Excel it is usually three years. For this example, it means that a video tutorial can be used for six semesters due to its reusability. Each tutorial can replace a one-hour seminar. The four hours of production time face six hours of saved personal supervision in seminars. In addition, students can use the video tutorials again at a later time to refresh their knowledge. Students with high prior knowledge can skip certain content and thereby acquire new knowledge more efficiently. To determine the frequency of the usage of video tutorials and the resulting need for videos more precisely, a follow-up study should be carried out, examining the real usage patterns of video tutorials, evaluated over the course of an entire semester. The creation process can be integrated into the course. The students create a video tutorial in groups while being supervised by a teacher. The resulting pool of video tutorials can be used by all students. The students acquire knowledge through experiential learning and learning by teaching.To determine whether this approach has an impact on the usage patterns and the learning, further investigations should be carried out. Through the integration of video tutorials in the knowledge management of companies, competence gaps of employees could be closed in the same way. Follow-up studies are also recommended in this area. 
Finally, it can be said that the use of video tutorials for the application of quality management tools using statistical and spreadsheet software allows a resourceefficient knowledge transfer while maintaining the quality of the results. Consequently, video tutorials are an effective tool to supplement teaching in this area of application.

\section{REFERENCES}

Balslev, T., De Grave, W., Muijtjens, A. and Schrepbier, A., 2005. Comparison of text and video cases in a postgraduate problem based learning format. Medical Education, 39(11), pp.1086-1092.

Baumeister, R.F., 2004. Handbook of self-regulation: research, theory, and applications. New York: Guilford Press.

Becher, A., 2012. Lernvideos auf YouTube. MSc. Technische Universität Dresden.

Chiappe, A., Segovia, Y. and Rincon, Y., 2007. Toward an instructional design model based on learning objects. Educational Technology Research and Development, 55(6), pp.671-681.

Coffee, J. and Hillier, S., 2008. Teaching pre-cursor clinical skills using an online audio-visual tool: an evaluation using student responses. Merlot Journal of Online Learning and Teaching, 4(4), pp.469-476.

Boster, F., Meyer, G., Roberto, A., Inge, C. and Strom, R., 2006. Some Effects of Video Streaming on Educational Achievement. Communication Education, 55(1), pp.46-62.

DeVaney, T. A., 2009. Impact of Video Tutorials in an Online Educational Statistics Cours. Journal of Online Learning and Teaching, 5(4).

Ehlers, U.-D., 2011. Qualität im E-Learning aus Lernersicht. Wiesbaden: Verlag für Sozialwissenschaften.

Eurostat, 2015a. Anteil der Beschäftigten in europäischen Ländern, die bei der Arbeit einen PC verwenden in den Jahren 2013 und 2014. [online] Available at: http://de.statista.com/statistik/daten/studie/162953/umfrage/anteil-dereuropaeischen-beschaeftigten-die-bei-der-arbeit-einen-pc-verwenden/ [accessed July 2015].

Eurostat, 2015b. Individuals' level of computer skills. [online] Available at: http://appsso.eurostat.ec.europa.eu/nui/show.do?dataset=isoc_sk_cskl_i\&lang=de [Accessed July 2015].

Fortino, V. and Zhao, W., 2012. Work in progress: video tutorials that enhance laboratory learning. Frontiers in Education Conference, Seattle, WA, 3-6 October 2012. 
Gardner, H., 2006. Multiple Intelligences: New Horizons. New York: Basic Books.

He, Y., Swenson, S. nad Lents, N., 2012. Online video tutorials increase learning of difficult concepts in an undergraduate analytical chemistry course. Journal of Chemical Education, 89(9), pp.1128-1132.

Jones, A.Y.M., Dean, E. and Hui-Chan, C., 2010. Comparison of teaching and learning outcomes between video-linked, web-based, and classroom tutorials: An innovative international study of profession education in physical therapy. Computer \& Education, 54(4), pp.1193-1201.

Kalz, M., Koper, R. and Hornung-Prähauser, V., 2009. Technology support for self-organized learners. Educational Technology \& Society, 12(3), pp.1-3.

Low, R. and Putai, J., 2012. Self-regulated learning. In: N.M. Seel, ed. 2012. Encyclopedia of the Sciences of Learning. Springer US. pp.3015-3018.

Morgan, P., Cleave-Hogg, D., McIlory, J. and Devitt, J., 2002. Simulation technology a comparison of experiential and visual learning for undergraduate medical students. Anesthesiology, 96(1), pp.10-16

Niegemann, H., 2004. Kompendium E-Learning. Berlin: Springer.

Preißer, R., 2006. Evaluation der Hochschullehre und Selbststeuerung des Lernens. In: Berendt, B., ed. Neues Handbuch Hochschullehre - Lehren und Lernen effizient gestalten. Berlin: Raabe Verlag.

Revermann, C., 2009. Europäische Wissensgesellschaft - Potenziale des eLearning. Berlin: Trafo Verlag.

Saadé, R., Bahli, B., 2005. The impact of cognitive absorption on perceived usefulness and perceived ease of use in on-line learning: an extension of the technology acceptance model. Information \& Management, 42(2), pp.317-327.

Schunk, D.H., 2004. Learning theories: An educational perspective. $4^{\text {th }}$ ed., Upper Saddle River: Pearson Education.

Stefanidis, D., Korndorffer, J.R., Heiniford, B.T. and Scott, D.J, 2007. Limited feedback and video tutorials optimize learning and resource utilisation during laparoscopic simulator training. Surgery, 142(2), pp.202-206.

Sun, P.-C., Cheng, H.K., 2005. The design of instructional multimedia in elearning: A media richness theory-based approach. Computers \& Education, 49(3), pp.662-676.

Siegel, P., Omer, K. and Agrawal, S., 1997. Video simulation of an audit: Experimental learning theory. Accounting Education, 6(3), pp.217-230.

Toutenburg, H. and Knöfel, P., 2007. Six Sigma: Methoden und Statistik für die Praxis. Berlin, Heidelberg: Springer Verlag. 
Truebano, M. and Munn, C., 2015. An evaluation of the use of video tutorials as supporting tools for teaching laboratory skills in biology. Practice and evidence of scholarship of teaching and learning in higher education, 10(2), pp.121-135.

Wieser, B., 2010. Videocasts - Der Einsatz von Videos im Lehr- und Lernprozess. Universität Wien.

Witten, H., Penon, J. and Dietz, A., 2006. SOL - Schule ohne Lehrer? Selbstorganisiertes Lernen im Informatikunterricht. LOG IN, 26(138/139), pp.7481.

Van der Meij, H. and Van der Meij, J., 2014. A comparison of paper-based and video tutorials for software learning. Computers \& Education, 78(September 2014), pp.150-159.

Van der Meij, H., Van der Meij, J., 2013. Eight guidelines for the design of instructional videos for software training. Technical Communication, 60(3), pp.205-228.

Wolters, C.A., 2010. Self-regulated learning and the $21^{\text {st }}$-century competencies. Department of Educational Psychology, University of Houston.

Worlitz, J. and Woll, R., 2015. Modellbau - Six Sigma für Kleinunternehmen. Qualität und Zuverlässigkeit, 60, 9, 10-11

Zimmermann, B.J., 2008. Investigating self-regulation and motivation: Historical background, methodological development, and future prospects. American Educational Research Journal, 45(1), pp.166-183.

\section{ABOUT THE AUTHORS}

Jane Worlitz, M.Sc. - Research associate, jane.worlitz@ b-tu.de

Anne Stabler, M.A. - Research assistant, anne.stabler@b-tu.de

Stefan Peplowsky, Dipl.-Ing. - Research associate, stefan.peplowsky@b-tu.de

Ralf Woll, Prof. Dr.-Ing., Chairholder - woll@b-tu.de Chair of Quality Management, Brandenburg University of Technology Siemens-Halske Ring 14, 03046 Cottbus, Germany. The Chair of Quality Management investigates industrial tasks from the perspective of engineers regarding quality, costs as well as time and we optimise processes using tools of quality-, project- and risk management. 